\title{
Correction to: An Application-Directed, Versatile DNA FISH Platform for Research and Diagnostics
}

\author{
Eleni Gelali, Joaquin Custodio, Gabriele Girelli, Erik Wernersson, \\ Nicola Crosetto, and Magda Bienko
}

Correction to:

Chapter 17 in: Tanya Vavouri and Miguel A. Peinado (eds.),

CpG Islands: Methods and Protocols,

Methods in Molecular Biology, vol. 1766, https://doi.org/10.1007/978-1-4939-7768-0_17

The original version of the chapter was inadvertently published with some errors and this has been corrected now:

In the 3.3.4 chapter, (page 315) where it is described how to make one buffer, there is $2.22 \mathrm{ml}$ instead of $1.11 \mathrm{ml}$.

3.3.4 uniFISH 1st hybridization buffer (1.1xUHB-1)

In the step 2:

It is "add $1 \mathrm{ml}$ of nuclease-free water and $1.11 \mathrm{ml}$ of $20 \times$ SSC buffer" instead of "add $1 \mathrm{ml}$ of nuclease-free water and $\mathbf{2 . 2 2} \mathrm{ml}$ of $20 \times$ SSC buffer"

The updated online version of this chapter can be found at

https://doi.org/10.1007/978-1-4939-7768-0_17 